\title{
Worldwide pesticide usage and its impacts on ecosystem
}

\author{
Anket Sharma ${ }^{1,2}$ (D) Vinod Kumar ${ }^{3} \cdot$ Babar Shahzad $^{4} \cdot$ Mohsin Tanveer $^{4} \cdot$ Gagan Preet Singh Sidhu $^{5} \cdot$ Neha Handa $^{2,6}$. \\ Sukhmeen Kaur Kohli ${ }^{2}$. Poonam Yadav $^{2}$. Aditi Shreeya Bali ${ }^{7}$. Ripu Daman Parihar ${ }^{8}$. Owias Iqbal Dar ${ }^{9}$. \\ Kirpal Singh $^{9} \cdot$ Shivam Jasrotia $^{9} \cdot$ Palak Bakshi $^{2} \cdot$ M. Ramakrishnan ${ }^{10} \cdot$ Sandeep Kumar $^{11} \cdot$ Renu Bhardwaj $^{2}$. \\ Ashwani Kumar Thukral ${ }^{2}$
}

(c) Springer Nature Switzerland AG 2019

\begin{abstract}
Pesticides are extensively used in modern agriculture and are an effective and economical way to enhance the yield quality and quantity, thus ensuring food security for the ever-growing population around the globe. Approximately, 2 million tonnes of pesticides are utilized annually worldwide, where China is the major contributing country, followed by the USA and Argentina, which is increasing rapidly. However, by the year 2020, the global pesticide usage has been estimated to increase up to 3.5 million tonnes. Although pesticides are beneficial for crop production point of view, extensive use of pesticides can possess serious consequences because of their bio-magnification and persistent nature. Diverse pesticides directly or indirectly polluted air, water, soil and overall ecosystem which cause serious health hazard for living being. In the present manuscript, an attempt has been made to critically review the global usage of different pesticides and their major adverse impacts on ecosystem, which will provide guidance for a wide range of researchers in this area.
\end{abstract}

Keywords Global pesticide usage · Pesticide application · Pesticide bio-magnification · Pesticide ecotoxicology

\section{Introduction}

Pesticides are the chemicals (natural or synthetic) employed in various agricultural practices to control pests, weeds and diseases in plants. Pesticides include a wide range of herbicides, insecticides, fungicides, rodenticides, nematicides, etc. In the process of agricultural development, pesticides became a vital tool for plant protection and for enhancing crop yield. Approximately, $45 \%$ of the annual food production is lost due to pest infestation; therefore, effective pest management by using wide range of pesticides is required to confront pests and to increase the crop production [1]. However, in the last half of the nineteenth century, robust growth in the world economy including both industrial and agricultural sectors has led to the progressive mount in the generation and utilization of agriculture-based chemicals which often induce calamitous effects on the environment. Injudicious use of pesticides and other persistent organic pollutants in agricultural soils have devastated future repercussions. The

Anket Sharma, Vinod Kumar and Babar Shahzad have contributed equally to this work.

$\triangle$ Anket Sharma, anketsharma@gmail.com |'State Key Laboratory of Subtropical Silviculture, Zhejiang A\&F University, Hangzhou 311300 , China. ${ }^{2}$ Plant Stress Physiology Lab, Department of Botanical and Environmental Sciences, Guru Nanak Dev University, Amritsar, Punjab 143005, India. ${ }^{3}$ Department of Botany, DAV University, Sarmastpur, Jalandhar, Punjab 144012, India. ${ }^{4}$ School of Land and Food, University of Tasmania, Hobart, TAS, Australia. ${ }^{5}$ Department of Applied Sciences, UIET, Chandigarh 160014, India. ${ }^{6}$ Department of Botany, School of Bioengineering and Biosciences, Lovely Professional University, Phagwara, Punjab 144411, India. ${ }^{7}$ Department of Botany, M.C.M. DAV College for Women, Chandigarh 160036, India. ${ }^{8}$ Department of Zoology, DAV University, Sarmastpur, Jalandhar, Punjab 144012, India. ${ }^{9}$ Department of Zoology, Guru Nanak Dev University, Amritsar 143005, India. ${ }^{10}$ Division of Plant Biotechnology, Entomology Research Institute, Loyola College, Chennai, India. ${ }^{11}$ Department of Environmental Sciences, DAV University,

Sarmastpur, Jalandhar, Punjab 144012, India.

SN Applied Sciences (2019) 1:1446 | https://doi.org/10.1007/s42452-019-1485-1

Received: 31 May 2019 / Accepted: 11 October 2019 / Published online: 21 October 2019 
persistent and ubiquitous nature of various agriculturebased pesticides and other organic pollutants has posed havoc to the mankind due to their bioaccumulation properties and high toxicity [2]. These pesticides are known to hinder the normal functioning of endocrine and reproductive systems in living organisms [3]. Certain pesticides like dichlorodiphenyltrichloroethane (DDT), chlordane, aldrin, dieldrin, endrin, mirex, heptachlor and hexachlorobenzene impart deleterious effects on human health and environment [4].

There may be other alternatives available to control crop loss due to pest attack which may include the application of various biopesticides. Developing some pest-resistant crop varieties using transgenic approaches is also one method to avoid pesticide use. But application of chemical pesticides is still preferred the most over all other alternatives to protect crops from yield loss. Presently, throughout the globe approximately 2 million tonnes of pesticides are utilized, out of which $47.5 \%$ are herbicides, $29.5 \%$ are insecticides, $17.5 \%$ are fungicides and $5.5 \%$ are other pesticides [5]. The top ten pesticide consuming countries in the world are China, the USA, Argentina, Thailand, Brazil, Italy, France, Canada, Japan and India [6]. Moreover, it has been estimated that by the year 2020, the global pesticide usage will increase up to 3.5 million tonnes [7].

Pesticides are applied to increase crop productivity; however, in due course of time, they get accumulated in plant parts, water, soil, air and biota. Extensive use of pesticides contaminates soil and water, remain in the crops and finally enter food chain, thereby posing threat to the human beings $[8,9]$. The commercial use of pesticides in agriculture produces vapors of pesticides that have the ability to become air pollutant [10]. The release of pesticides into the air largely depends upon the physical and chemical properties of the active compound, application procedure and changing environment conditions [11, 12]. Further, the volatilization of water adds pesticides into the air. The pesticides get dispersed and transported from one site to other in the form of degraded products [13]. Pesticides used in agriculture are synthetic in origin and get absorbed in the soil through surface runoff from treated plants. The nature of organic compound, cropping practices, irrigation techniques and climatic factors influence the dissolution of pesticides in soil [14]. The residues of these organochlorine compounds further pollute the groundwater through leaching and in turn affect the quality of agricultural crops. Pesticides get accumulated in soils directly by its application in agriculture and domestic purposes or indirectly by deposition of airborne contaminants previously coming from different sites or areas. Soil serve as storage compartments due to high affinity of organic chemicals with soil [15]. The deposition of organic chemicals or pesticides in soil directly exposes soil organisms and also increases the risk for other higher organisms through diet and can severely affect soil ecosystem, water bodies, plants and human health [16-19]. Keeping in mind the extensive use of pesticides throughout the globe, the present review gives an overview about the application of pesticides in the world and their various impacts on the ecosystem.

\section{Pesticides used worldwide}

\subsection{Pesticide usage in Africa}

The economy of Africa is largely dependent on agriculture, and nearly $59 \%$ of the population makes their living from farming [20]. Despite that, the African continent has a contribution of $2-4 \%$ of global market share of pesticides which also accounts for the lowest rate of their usage in the world [20]. Due to increasing population, the food demand has been projected to enhance at a rapid rate in the next three decades and thus, demand of pesticides, herbicides and fungicides is also likely to enhance [21]. Table 1 summarizes the usage of pesticides in various
Table 1 Pesticide usage in African countries in the years 2010 and 2014, index on the basis of their area. (modified after Lobin et al. [22])

\begin{tabular}{llrll}
\hline S. no. & African countries & Area $\left(\mathrm{km}^{2}\right)$ & $\begin{array}{l}\text { Quantity of pesticide used } \\
\text { in } 2010(\mathrm{~kg} / \mathrm{ha})\end{array}$ & $\begin{array}{l}\text { Quantity of pesticide } \\
\text { used in 2014 (kg/ha) }\end{array}$ \\
\hline 1. & Congo & $2,345,000$ & 3.61 & 3.03 \\
2. & Sudan & $1,886,068$ & 0.09 & 0.25 \\
3. & Cameroon & 475,442 & 1.22 & $\mathrm{NA}$ \\
4. & Zimbabwe & 390,757 & $\mathrm{NA}$ & 0.53 \\
5. & Malawi & 118,484 & 0.15 & 0.60 \\
6. & Togo & 56,785 & 0.09 & 0.25 \\
7. & Rwanda & 28,338 & 0.69 & 1.47 \\
8. & Burundi & 27,834 & 0.19 & $\mathrm{NA}$ \\
9. & Mauritius & 2,040 & 28.17 & 27.19 \\
\hline
\end{tabular}

NA Data not available 
African countries based on their area in the 2010 and 2014. The data show that the usage of pesticides declined in Congo and Mauritius, while in Sudan, Malawi, Togo and Rwanda, it increased in the years 2010-2014.

In order to maintain high yields and profits, pesticide usage becomes a necessity in agriculture [23]. Also, most of the governments encouraged the usage of pesticides since 1970 and in 1990s, amendment in several policies led to reduction in input subsidies. Such changes in policies resulted in even less monitoring by the governments. Due to this, more inflow occurred from the informal channels that caused enhanced usage of pesticides, leading to an increased import value by $261 \%$ from 2000 to 2010 [23]. Inadequate regulatory mechanisms also result in import of pesticides which are banned, and lack of awareness in the farmers causes poor pesticide practices. Pesticide registration in Western Africa is a multi-national process called as Comité Sahélien des Pesticides (CSP) [24]. It was reported that in Niger, due to limited capacity of CSP, $44 \%$ of pesticide dealers are unlicensed. Also, the registered chemicals account for only $8 \%$, while $38 \%$ of pesticides have incomplete labels and $6 \%$ are unlabeled [25]. The same report also specified that $27 \%$ of the tested pesticides did not state the active ingredients and $30 \%$ of them belonged to poor quality. Apart from Niger, CSP was not able to implement its laws strictly in other parts also, and as a result, the pesticide importers, distributers and users could not be certified. Furthermore, among the domestically produced pesticides, the high-quality ones are exported, while the low-quality pesticides are supplied to local farmers [24]. Hence, the African market is unregulated and does not comply with the code of conduct laid out by Food and Agriculture Organization due to which most of the pesticides used are untested leading to the enhanced risks.

In Africa, lack of knowledge about the usage of pesticides has also led to the usage of those pesticides which fall under WHO risk classification system. According to Pesticide Risk Reduction Program (PRRP, [26]), in Ethiopia alone, out of 302 registered pesticides, 160 contained active ingredients which were classified as WHO class II chemicals (moderately hazardous). Case studies of other African countries also showed the usage of pesticides which were hazardous according to the WHO risk classification system. A study by Obopile et al. [27] in Botswana showed that over $50 \%$ of farmers use malathion and cypermethrin as pesticides and these are WHO class II chemicals. The same study also pointed that in Botswana, methomyl is used by $7.1 \%$ of farmers, demeton-S-methyl is used by $2.7 \%$ farmers, and dichlorvos is used by $1.8 \%$ farmers, and all these chemicals are classified under WHO class Ib pesticides (highly hazardous). A similar study conducted by Oluwole and Cheke [28] in Nigeria established that maximum farmers (78\%) use monocrotophos which comes under WHO class Ib chemicals. Other pesticides that were reported included atrazine and metolachlor which fall under WHO class III chemicals (slightly hazardous), and lindane, copper sulfate and paraquat which are WHO class II chemicals. Nyirenda et al. [29] reported the usage of monocrotophos (lb) by $41 \%$ farmers in Zambia, while in Malawi, parathion, a WHO class la pesticide (extremely hazardous), is used by over $25 \%$ of farmers. Other commonly used active ingredients in pesticides include glyphosate (III), malathion (III), chlorpyrifos (II), cypermethrin (II), deltamethrin (II), dimethoate (II), endosulfan (II), fenitrothion (II) and profenofos (II). These mentioned pesticides are frequently used in Benin, Ethiopia, Ghana and Senegal [30].

The common risk linked with pesticide usage is the resistance of the pests that leads to destruction of the crops despite appropriate application. It has been reported in western part of Africa that the use of pyrethroids has caused resistance in tomato bollworm (Heliothis armigera Hübner) and diamondblack moth (Plutella xylostella L.) $[23,31]$. Also, resistance to pyrethroids and organophosphates was seen in an aphid (Aphis gossypii Glover), while a whitefly (Bemisia tabaci Gennadius) has been reported to develop resistance against pyrethroids, organophosphates and neonicotinoids [32,33].

\subsection{Pesticide usage in Asia}

The use of pesticides in agriculture is increasing rapidly in developing countries, especially in Southeast Asia [34, $35]$. WHO has reported that approximately $20 \%$ of pesticides are used in developing countries with increasing rate of usage. An annual increase in import of pesticides is reported as $61 \%$ for Cambodia, $55 \%$ for Laos and $10 \%$ for Vietnam [36].

The manufacturing of pesticides in India started in 1952, with the production of benzene hexachloride, followed by DDT. The synthesis of pesticides increased enormously. In 1958, India manufactured over 5000 metric tonnes of pesticides which increased to 85,000 metric tonnes in the mid-1990s with the registration of 145 pesticides and the major pesticides produced are insecticides [37]. India is one of the major pesticides producing countries in Asia with annual production of 90,000 tonnes, and it stands at twelfth position in the world in the manufacturing of pesticides [38]. In the past, India used and exported organochlorine pesticides on large scale including DDTs and $\mathrm{HCHs}$ [39]. Similarly, in Pakistan, the pesticides usage started in 1954 with the import of 250 metric tonnes [40]. The pesticides consumption in Pakistan increased to 78,132 tonnes per annum in 2003 [38, 41]. During Green Revolution period, thousands of tonnes of pesticides had been imported from Europe and the USA to control crop pest infections, locust control and suppression of malaria 
in Pakistan [42]. Use of pesticides in Bangladesh was low until 1970. The pesticide usage increased tremendously from 2200 million tonnes in 1980-1982 to 6500 million tonnes in 1992-1994 [43]. In Nepal, the first reported use of pesticides was DDT in 1956, which was followed by other organochlorines, organophosphates, carbamates and synthetic pyrethroids. It has been reported by plant protection division of department of agriculture, approximately 55.8 metric tonnes of pesticides is used annually in Nepal [44]. In Sri Lanka, the pesticides are mainly used in agriculture sector. DDT was the first pesticide used in Sri Lanka after World War II for malaria eradication. Pesticides were introduced in Thailand and Vietnam in mid-1950s. In Vietnam, the use of pesticides accelerated in mid-1980s during economic liberalization. The use of pesticides in agriculture increased from 20 to 30 million $\mathrm{kg}$, and it further increased to 77 million $\mathrm{kg}$ in 2007 [45].

Table 2 Annual pesticide consumption in different Asian countries [47]

\begin{tabular}{llr}
\hline S. no. & Country & \multicolumn{1}{c}{$\begin{array}{l}\text { Tonnes } \\
\text { pesticides } \\
\text { used }\end{array}$} \\
\hline 1 & China & $1,807,000$ \\
2 & India & 56,120 \\
3 & Malaysia & 49,199 \\
4 & Pakistan & 27,885 \\
5 & Thailand & 21,800 \\
6 & Vietnam & 19,154 \\
7 & South Korea & 19,788 \\
8 & Bangladesh & 15,833 \\
9 & Myanmar & 5583 \\
10 & Nepal & 454 \\
11 & Bhutan & 12 \\
\hline
\end{tabular}

In China, pesticide production started in 1950 with the manufacturing of DDT. China has become the largest pesticide manufacturing country during past 50 years of development. In China, pesticides are mainly used for rice production. The consumption of pesticides in China has increased from 76 million tonnes in 1991 to 146 million tonnes in 2006. Japan is one of the largest pesticide consumers in the world and has biggest pesticide market in Asia [46]. Table 2 shows the consumption of different pesticides in the Asian countries.

\subsection{Pesticide usage in Australia}

In Australia, farmers have been prepared to incur higher chemical costs to cope with pests effectively. Primary categories of pesticides are herbicides, insecticides, fungicides and some growth regulators, overall costing a total market value of $A \$ 187$ million annually [48]. Herbicides costs include use of alternate herbicide and mixtures along with higher concentration rates posing an extra cost of $A \$ 8 /$ ha. A pictorial description of pesticide consumption in Australia is shown in Fig. 1. Several concerns affect choice for herbicide selection including possible development of herbicide resistance, price of herbicide, residual impact on non-target organisms including operators and community, market implications and overall impact on other strategies such as integrated pest management [49].

Weed infestation leads to great reductions in crop productivity along with deteriorating the quality of the production. Application of herbicides for effective weed control upsurges agricultural productivity, making it desirable option for farmers. Herbicide utilization proves an effective approach for controlling weeds; however, overuse of these herbicides causes several complications such as development of herbicide-resistant biotypes due to the overuse of herbicides having common mode of action [50]. Evolution
Fig. 1 Pesticide consumption in Australia [99]

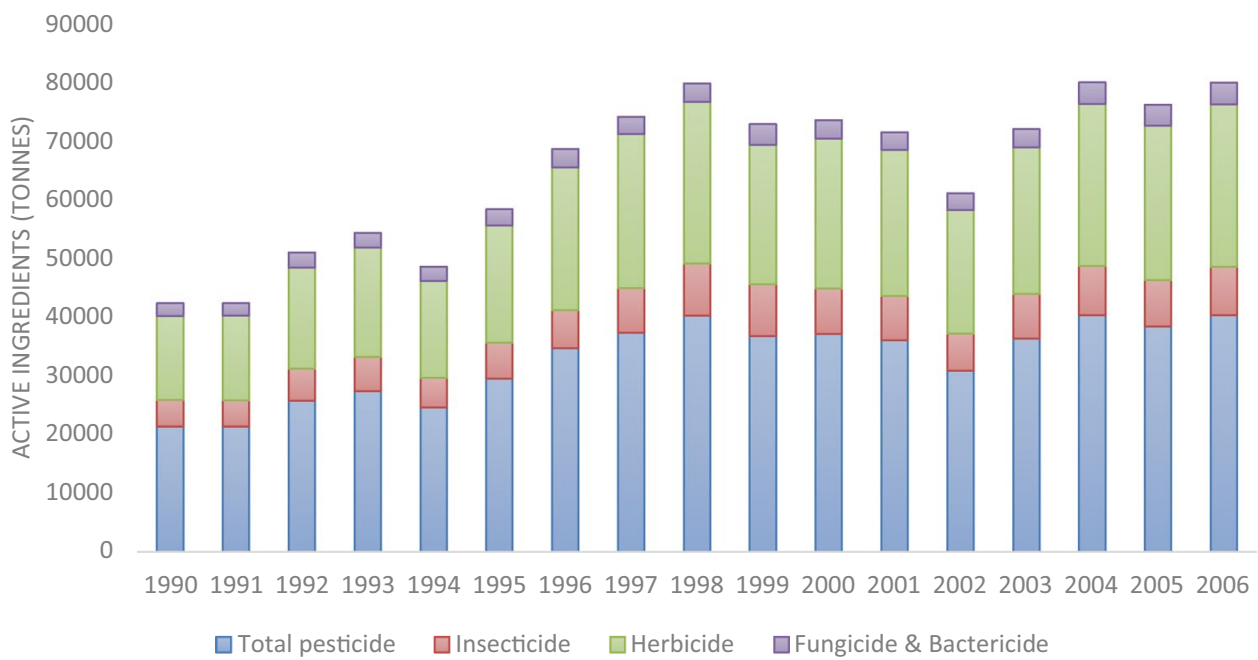


of herbicide-resistant weed biotypes is a serious problem that is now infesting crops throughout Australia [51-53]. Conservational agricultural systems completely rely on the use of efficient herbicides owing to their low cost and selective weed control in intensive farming systems [54]. However, development of herbicide resistance under continues use of herbicides has increased an average cost of A $\$ 55 /$ ha for effective weed control [48].

Under continuous use of herbicides for selective weed control, development of herbicide resistance in weed biotypes has become the overwhelming threat for effective weed control in global wheat production system [54]. Application of herbicide in higher concentrations has resulted in creating more diversity in herbicide resistance. Weed populations in wheat crop are now frequently resistant and contain numerous mechanisms conferring herbicide resistance [55]. In Australia, herbicide-resistant weeds such as L. rigidum, Avena spp., R. raphanustrum, Bromus spp. and Hordeum spp. have been the most dramatic and extensive weeds [50,51,56-59]. Moreover, excessive application of pesticides/weedicides develop resistance in pests/weeds, thus making it difficult to control their population. In Australia, a dramatic increase in the population of herbicide-tolerant ryegrass in different regions has been reported (Fig. 2). Some weeds have also developed resistance against herbicides which work by the mechanisms like ACCase inhibition [60, 61] and ALS inhibition [62]. In Western Australia, it has been reported that common weed Avena has also developed resistance against those herbicides which work on the mechanism of inhibiting activity of acetyl-CoA carboxylase [63]. Similarly, L. rigidum, another widely spread annual weed in Western Australia, has observed to gain resistant mechanism against ACCase- and ALS-inhibiting herbicides like diclofop methyl and sulfometuron [59]. These results suggested to adopt conservation agriculture or to control weed proliferation via crop weed competition approach.

\section{Herbicide resistant Rye grass population in Australia}
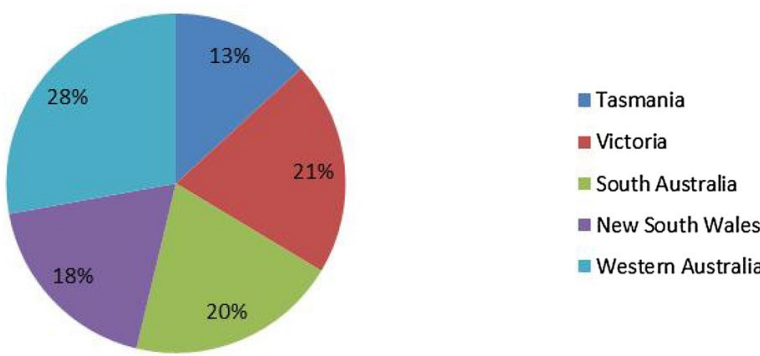

Fig. 2 Abundance of herbicide-resistant ryegrass population in different regions of Australia. (modified after Peterson et al. [64])

\subsection{Pesticide usage in Europe}

The infestation of agricultural lands in the European countries has occurred rapidly due to enhanced application of insecticides, herbicides, fungicides and chemicalbased fertilizers. This eventually has resulted in loss of natural habitat and heterogeneity of the farmlands and other landscapes $[65,66]$. A joint survey of seven European countries including Latvia, Denmark, Germany, the Netherlands, Finland, Sweden and the UK was done on the usage of pesticides in their urban or the non-agricultural amenities [67]. In the urban areas, herbicides constitute the major pesticide contaminants. The analysis was carried in different regions and demonstrated wide variation in political interest and public discussion on "use of pesticides in urban areas", regulation and availability of statistical data on pesticide usage. Moreover, it was reported that Denmark, the Netherlands, Germany and Sweden had a very strong political as well as public interest in lowering the application of herbicides in their urban areas to control weed. Although the UK is undergoing an episode of enhanced awareness and stringent regulations, Finland and Latvia have no specific regulation for lowering pesticide usage [67]. Although the use of pesticide has enhanced in Finland, the rate is comparatively lower when compared to other European regions [68]. It was estimated to be 5-6 metric tonnes of pesticides with active ingredients per year. A survey in 2007 was carried out in 80 Finish municipalities. One-fifth of these municipalities reported occasional of these pesticides and only about $15 \%$ of these municipalities used pesticides [67]. Determinations of pesticide in 8 different hot springs were carried out by Karasali et al. [69] in Greece. From 26 different samples, pesticides were reported in 14 of them although they did not exceed the European Union Maximum Acceptable Concentration (MAC). Lindane ( $\gamma-\mathrm{BHC})$ was the most commonly occurring pesticide. It was found in $35 \%$ samples with levels ranging from 0.005 to $0.01 \mu \mathrm{g} / \mathrm{L}$. Few other pesticides detected included propachlor, phorate and chlorpyrifos ethyl, but were below the permissible limits.

Table 3 summarizes pesticide usage in European countries in the years 2010 and 2014, index on the basis of their area. Tabulated data showed that a few European countries including Denmark, France, Austria and the Netherlands reduced pesticide usage, while in others like Germany, Greece, Ireland, Czech Republic, Spain and Portugal, the usage was enhanced.

Pesticide and fertilizer usage in the Ukraine region was lowered from 4.2 million tonnes nutrient in 1990 to about 518 tonnes nutrient in the year 2004. Specifically, in the case of wheat, the quantity of pesticides applied in the year 1990 was $149 \mathrm{~kg} / \mathrm{ha}$ which was reduced to $26 \mathrm{~kg} / \mathrm{ha}$ in the year 2003. There are approximately 170 pesticides 
Table 3 Pesticide usage in European countries in the years 2010 and 2014, index on the basis of their area. (modified after Lobin et al. [22])

\begin{tabular}{|c|c|c|c|c|}
\hline S. no. & European countries & Area $\left(\mathrm{km}^{2}\right)$ & $\begin{array}{l}\text { Quantity of pesticide } \\
\text { used in } 2010(\mathrm{~kg} / \mathrm{ha})\end{array}$ & $\begin{array}{l}\text { Quantity of pesticide } \\
\text { used in } 2014(\mathrm{~kg} / \mathrm{ha})\end{array}$ \\
\hline 1. & France & 551,394 & 1.17 & 3.90 \\
\hline 2. & Spain & 498,468 & 2.77 & 3.35 \\
\hline 3. & Sweden & 449,964 & 0.68 & 0.72 \\
\hline 4. & Germany & 357,168 & 3.39 & 3.80 \\
\hline 5. & Italy & 301,318 & 7.34 & 6.45 \\
\hline 6. & Greece & 131,940 & 1.51 & 2.58 \\
\hline 7. & Portugal & 91,568 & 7.40 & 6.84 \\
\hline 8. & Austria & 83,858 & 2.53 & 2.39 \\
\hline 9. & Czech Republic & 78,866 & 1.59 & 1.45 \\
\hline 10. & Ireland & 70,273 & 2.50 & 2.84 \\
\hline 11. & Denmark & 44,493 & 1.61 & 0.71 \\
\hline 12. & Netherlands & 41,198 & 9.05 & 9.86 \\
\hline 13. & Belgium & 30,510 & 5.43 & 7.73 \\
\hline
\end{tabular}

used in Ukraine of which 49 were extremely toxic, stable and super accumulative [70]. Approximately, 20\% Ukraine agricultural land is polluted with DDT and $4 \%$ is contaminated with hexachlorocyclohexane [71]. In the urban areas of Ukraine, near the pesticides storehouses are still the main source of pesticide in the soil. Since long time, these stores have been used to store large quantities of hazardous pesticides [72]. The approximate pesticide product used in 2000 was about $3.1 \mathrm{~kg} / \mathrm{ha}$ in the agricultural lands of Slovenia [73]. Fava et al. [74] investigated the presence of 43 hazardous pesticides and their pesticide residue on the basis of their sales, physical-chemical data and monitoring in the Italian region. Of these, 12 compounds were identified in the drinking water as determined by the European Directive 98/83/EC. It was determined that the total concentration of specific pesticides and their metabolites were more than $0.5 \mu \mathrm{g} / \mathrm{L}$. Triazine levels were found to be more than $1.02 \mu \mathrm{g} / \mathrm{L}$. Ferencz and Balog [75], estimated the quantity of wide arrays of pesticide in water, food stuff and soil samples from the Central Romanian region. The most significant pollutants are as follows: (1) a-hexachlorocyclohexane (6 ng/L), (2) $\mathrm{Y}$-hexachlorocyclohexane (4 ng/L), (3) diazinon (20 ng/L), (4) dichlorvos (20 $\mathrm{ng} / \mathrm{L})$ in different water samples. The level of DDT was $20 \mu \mathrm{g} / \mathrm{kg}$ and DDE was $50 \mu \mathrm{g} / \mathrm{kg}$ in the contaminated soil. Table 4 elaborates pesticide usage $(\mathrm{kg} / \mathrm{ha})$ in European countries in the years 2001-2012 in the arable land and permanent crops. The countries are indexed on the basis of area (Table 4).

In the autumn session of 2000, Environmental Protection Agency proposed that the pesticides which had glyphosate as one of their bioactive ingredients which was applied to the hard surfaces [76], are restricted or banned to be used on the hard surfaces. Therefore, the weed control in these areas is no longer carried out by applying these pesticides [77]. The statistical details of Danish Environmental Protection Agency in the years 1995-2007 revealed that the pesticide usage is reduced by 288 tonnes to 5.1 tonnes of active ingredient, and in the case of pesticide, it has been reduced by $81 \%$ of total pesticides. In 2000, A "Plant Protection Products"Trade and Usage division was setup in Latvia, Europe, and in late 2002 a "Plant Protection Products" Circulation Control Organization was established. In the Netherlands, in 2004 a National Administrative Organization Water (NAOW) was formed to control "weeds on hard surfaces." Their goal was to develop cost-effective and permissible practice to control weeds [67]. A statistical analysis of usage of pesticides is carried out every year by the "Sewdish Chemical Inspectorate" since the year 2006 [67]. The government local authorities are making efforts in the UK to improve the efficacy of cleaner, greener and safe surrounding agenda [78].

European countries have developed certain imperative legislation in regard to pesticides usage and these include (1) Directive 2009/128/EC approved by European Parliament and Council in the year 2009: This directive is employed to attain techniques to sustainably use pesticides; (2) Regulation (EC) No. 1107/2009, proposed in the European Parliament and Council in the year 2009: This regulation maintains Plant Protection Products on the market; and (3) Regulation (EC) No. 396/2005 was proposed in the year 2005 by the European Parliament and Council: It monitors the MRLs of pesticide in the food products as well as animal and plant derived feeds [22]. Furthermore, the Russian government has formulated certain policies to enhance the availability of pesticide and their usage. These policies led to an increase in import, subsidies to farmers to procure pesticides and construction of manufacturing plants [79]. Another European Community (EC) Pesticide Legislation on the agricultural lands in Ireland determined 
Table 4 Pesticide usage (kg/ ha) in European countries in the years 2001-2012 in the arable land and permanent crops (modified after Lamichhane et al. 2016)

\begin{tabular}{|c|c|c|c|}
\hline S. no. & European Countries & Area $\left(\mathrm{km}^{2}\right)$ & $\begin{array}{l}\text { Quantity of Pesticide Used from } 2002 \text { to } 2012 \\
\text { in Arable lands and permanent crops (kg/ha) }\end{array}$ \\
\hline 1. & France & 551,394 & 3.43 \\
\hline 2. & Spain & 498,468 & 2.08 \\
\hline 3. & Germany & 357,168 & 2.26 \\
\hline 4. & Finland & 338,145 & 0.67 \\
\hline 5. & Poland & 312,685 & 1.12 \\
\hline 6. & Italy & 301,318 & 6.90 \\
\hline 7. & United Kingdom & 244,820 & 3.60 \\
\hline 8. & Romania & 238,392 & 0.74 \\
\hline 9. & Greece & 131,940 & 2.59 \\
\hline 10. & Hungary & 93,030 & 1.75 \\
\hline 11. & Portugal & 91,568 & 6.78 \\
\hline 12. & Austria & 83,858 & 2.25 \\
\hline 13. & Czech Republic & 78,866 & 1.30 \\
\hline 14. & Ireland & 70,273 & 2.27 \\
\hline 15. & Lithuania & 65,300 & 0.73 \\
\hline 16. & Latvia & 64,589 & 0.61 \\
\hline 17. & Slovakia & 49,036 & 0.99 \\
\hline 18. & Estonia & 45,339 & 0.63 \\
\hline 19. & Denmark & 44,493 & 1.31 \\
\hline 20. & Netherlands & 41,198 & 8.30 \\
\hline 21. & Belgium & 30,510 & 8.48 \\
\hline
\end{tabular}

that around $5 \%$ of agriculture area in the northern region of Ireland accounts for $69 \%$ of land treated with pesticides [80]. It was further reported in 2014 that fruit crop-growing areas of Northern Ireland had 30 types of pesticides with active constituents applied to approximately to 34,763 ha [81]. Presently in the Northern Ireland, the Pesticide Legislative Regulations are applied through Control of Pesticide Regulation, 1997, and Control of Substances Hazardous for Health and Regulation, 2003 [80].

\subsection{Pesticide usage in the North/Central America}

In North America, herbicides are largely used as chemical tool to manage weeds due to high labor cost in these areas [82]. Likewise, the use of certain insecticides to manage insects that cause vector-borne diseases like malaria is the only feasible option for prevention [83]. The main use of pesticides in the USA is in the agriculture industry [84]. Annually, 500 million $\mathrm{kg}$ of pesticides are used in the USA at a cost of $\$ 10$ billion per year [85]. Atwood and Paisley-Jones [86] formulated a report and found that the USA accounts for approximately $16-18 \%$ of total world pesticide expenditure. Among the agriculture sector, herbicides ( 59\%) accounted for major pesticide expenditure, followed by insecticides ( 14\%) and fungicides ( 10\%). The magnitude of herbicide usage not only intensifies on croplands but on the wild lands as well. The researchers from University of Montana revealed that in the year 2010, approximately 200 tonnes of herbicides were sprayed on 1.2 million acres federal and tribal wild lands of USA [87]. However, in spite of its extensive implementation in the USA, pests mainly insects, weeds and pathogens ruin $37 \%$ of crops [88]. According to the report of Pimentel et al. [89], the use of insecticides (chiefly organochlorines, organophosphates and carbamates) in the USA has increased 10 times from 1945 to 2000; however, the damage caused by insects to crop also doubled from 7 to $13 \%$ during this period. Atwood and Paisley-Jones [86] listed 25 most commonly used pesticides in the agricultural fields and found that 12 are herbicides, two insecticides, four fungicides, five are fumigants and two are plant growth regulators. Among the different pesticides used in the agricultural fields, glyphosate is the most used active pesticides since 2001 , followed by atrazine and metolachlor-S. Wagner et al. [90] illustrated manifold increment in the usage of herbicides in croplands of the USA. They further confirmed that glyphosate was the most active ingredients that not only harm the herbs and grasses but also pose potential threat to the native vegetation [90]. Benbrook [91] documented that since 1974, above 1.6 billion $\mathrm{kg}$ of active ingredients of glyphosate have been applied in the USA which contributes to $19 \%$ of the estimated global use. The researcher further documented that in the last 10 years, US farmers sprayed over two-thirds of the total volume 
of glyphosate from 1974 to 2014 which is approximately $1.0 \mathrm{~kg} / \mathrm{ha}$ [91]. A report from Allied Market Research (AMR) demonstrated that the volume of glyphosate ingredient is expected to grow at a compound annual growth rate (CAGR) of 5.7\% during 2014-2020 [92]. According to this report, the USA will hold the largest herbicide market share in North America and would produce $85 \%$ of North America market revenue in 2020 [92]. Further, in non-agriculture sectors such as home and garden, 2, 4-D is the most commonly used pesticide and is ranked first among other known pesticides. Currently, the insecticides consumption in the USA has declined due to shift toward biopesticides and other natural plant products.

Similarly, in Canada, 35 million $\mathrm{kg}$ of pesticides are used annually in agricultural fields [93]. Herbicides are the most prominent and widely used chemical pesticides in Canada [94]. Moreover, herbicides cover approximately $96 \%$ of total pesticides applied in Prairie Provinces of Canada [93]. In a survey made in the year $2011,69 \%$ of the Canadian agricultural crop lands were reported to apply herbicides in order to mount the crop productivity [95]. Wilson [96] used crop insurance data from Manitoba and found that 2 million $\mathrm{kg}$ of herbicides are used annually in the province. According to Verrin et al. [97], the commonly used pesticides in British Columbia includes 2, 4-D, diazinon, dicamba, atrazine and simazine. These agricultural herbicides can directly cause mortality of species since they are chemically toxic [98]. Recently, statistics showed that the total amount of pesticides imports to Canada comprised of 1.32 billion U.S. dollars [99].

Mexico is the third largest market of agrochemicals in North America, and its market is growing at a CAGR of 5.2\% during 2017-2022. The major agrochemicals include insecticides and herbicides that account for approximately $36 \%$ of the total market [100]. Earlier, Mexico ranked sixth in the world for the use of DDT (dichlorodiphenyltrichloroethane) [101]. Wong et al. [102] reported that between the years 1947 and 2000, approximately 250 kilotonnes of DDT was used in the country; however, the use of DDT was successfully halted by 2000 [103]. Mexico actively participates in different international agreements dealing with pesticides; however, studies have reported that Mexico still uses some pesticides such as paraquat, endosulfan, lindane, methyl bromide, parathion and malathion that are banned in other industrialized countries [104].

\subsection{Pesticide usage in South America}

In South America, pesticide sale increased $30 \%$ between 2003 and 2004 and was projected to increase from 5.4 billion (US \$) in 2004 to 7.5 billion (US \$) by 2009. The average annual growth rate for this period was $5 \%$. Pesticides like 2, 4-D, paraquat, methamidophos, methomyl, endosulfan and chlorpyrifos had the maximum share in pesticide sale. In some countries of South America, mean usage rate of pesticides in arable lands determined by FAO is $6.5-60 \mathrm{~kg} / \mathrm{ha}$ [105]. In Brazil, during the year 2013, it has been reported that half million tonnes of pesticides were marketed. Moreover, it has also been noticed that over $90 \%$ Brazilian farmers are dependent on pesticide usage [106], and the country has estimated to had used over 673 million tonnes of pesticide in 2008 [107]. The sale of pesticides increased 945.5\% in Brazil between 1998 and 2008. In the year 1996, out of total sold pesticide, herbicides were sold most $(56.1 \%)$ followed by insecticides $(26 \%)$ and fungicides (15.4\%) [108]. Soares and de-Souza Porto [109] evaluated the environmental, social and health cost due to intensive pesticide use in Brazil. They have reported that the cost of acute poisoning to around $64 \%$ using insecticides and herbicides in maize which may reach up to $85 \%$ in the next ten years.

In Argentina, agrochemical application has significantly enhanced and it has been observed that total consumption has inclined from 73 to 236 million $\mathrm{kg} /$ year over last decade. This accounts for turnover of 2381.16 million (US \$) in the year 2012. Out of all pesticides sold during this period, maximum was herbicides (64\%) followed by fungicides (20\%) and insecticides (16\%) [110]. In Argentina, pesticide market is mostly captured by herbicides $(86.8 \%$ and mostly used herbicides are glyphosate, 2,4-D and atrazine) followed by insecticides $(6.2 \%$ and mostly used insecticides are cypermethrin, chlorpyrifos, lambda-cyhalothrin) and fungicides ( $2.7 \%$ including epoxiconazole, tebuconazole and metconazole) [111]. During the time period from 1974 to 2003, in Colombia the registration of pesticide sharply increased to 400 from 186 active ingredients [112].

\section{Pesticide contamination and its impacts on global ecosystem}

Pesticides have become an environmental hazard as their safe storage and disposal are challenges [113]. Pesticides, when used in high quantities, pollute soil and water, causing damage to its microflora and microfauna, and also hinder the absorption of important mineral nutrients by plants [114]. To measure the ecological-toxicology of pesticides, indexes like Environmental Impact Quotient and Environmental Risk Index have been used [23]. In Benin, carbofuran, chlorpyrifos ethyl and endosulfan showed highest Environmental Risk Index [115]. The leaching of pesticides also leads to the pollution of the local water bodies. For example, the catchment area of the Lake Victoria in Kenya has six rivers that carry pollutants to the lake [113]. Winam Gulf is the most polluted part of this lake and pesticide poisoning of fishes with endosulfan 
was reported, and a ban on import of fishes from the lake was imposed by the European Union [113, 116]. Pesticides leach to the groundwater and pollute drinking water, which is one of the major concerns for environmentalists [117]. A study showed the presence of malathion, dieldrin and $\mathrm{\gamma}-\mathrm{HCH}$ in the ground water and River Ganges in Kanpur [118].

Water streams contamination with pesticides is one of the serious issues in Australia. Application of triazine (a herbicide) had been extensively practiced in forestry industry in Tasmania, Australia. Reports suggested that out of 29 streams sampled, 20 contained detectable residues of triazines [119]. Median contaminations of all the samples were 2.85 and $1.05 \mu \mathrm{g} / \mathrm{L}$ for atrazine and cyanazine, while $<0.05 \mu \mathrm{g} / \mathrm{L}$ for each of metribuzin and propazine, respectively, suggesting that observed residues may cause occasional minor short-term disturbance to stream communities [119]. Residual impact of herbicide runoff from adjacent agricultural catchments is other manifestation of pesticide application. This pesticide runoff has led to the deprivation of costal and inshore ecosystems of Great Barrier Reef (GBR) [120-123]. Potential hazardous impacts of herbicide runoff have been emphasized through a range of keystone GBR marine organisms containing seagrass, corals and algae [124-127]. According to an estimate, $30,000 \mathrm{~kg}$ of herbicides (including atrazine, diuron, ametryn, simazine, hexazinone and tebuthiuron) have been noticed to pass into GBR World Heritage Area per year $[128,129]$. However, majority of herbicides measures each year in sediments comprise of atrazine and diuron [130]. Davis et al. [131] examined seasonal dynamics in relation to movement of pesticides within agriculture captured floodplains of the lower Burdekin River. Fifteen herbicides along with one insecticide were detected in local waterways draining into the downstream of wetlands. These researchers observed that out of detected pesticides, maximum was related to sugarcane industry [131]. Atrazine and ametryn along with their degraded products (desethyl-atrazine and desisopropyl-atrazine), diuron, 2, 4-D and hexazinone were the main agrochemicals detected in higher concentrations [131]. Some other studies have documented that several herbicide residues including diuron were detected in benthic deposits tested from irrigation and drainage channels, suggesting diuron being the most abundant herbicide in terms of occurrence $[132,133]$. Likewise, diuron was dominantly found in interand sub-tidal deposits of GBR $[134,135]$. In Melbourne, Allinson et al. [136] examined water quality of five different aquatic systems and found that many pesticides were present in high concentrations which included MCPA (83\%), diuron (63\%) and atrazine (53\%). In another study, water screening from wetlands resulted in the detection of many harmful pesticides (simazine, atrazine and terbutryn) in high concentrations (Allinson et al. [137]).

The enhanced concentration of organochlorine pesticides and polychlorinated biphenyls in the Canadian Great Lakes Basin [138] and various fungicides in surface and ground water resources in the USA [139], posed a serious problem over the health-related issues of local communities as well as the environment. The direct discharge of waste and agriculture runoffs are major sources of pesticides in water [140]. The pesticides accumulated in water get magnified through food chain and enter fishes that are toxic for human consumption [141]. In most of the studies conducted in North America, glyphosate [142] and atrazine [143] are the two commonly found pesticides in water bodies and other pesticides found in less concentration are malathion, chlorpyrifos, diazinon, lindane, dieldrin and dichlorodiphenylethane (DDE) [101]. Benbrook [91] found that the use of glyphosate in the US agricultural sector increased 300 times from 1974 to 2014 and this herbicide is in the market of the USA for the past 42 years. Murray [144] reported that the regulations which govern the production and distribution of pesticides in Central America are not enforced adequately. As a result, compounds banned in other developed countries are used continuously in Central America [145]. For example, DDT, a persistent organochlorine pesticide, is still used for control of vector in Belize [146]. The highly protected area of the coast of Mexico was also contaminated with pesticides such as DDT, lindane and endosulfan [147] which might be due to their use in agricultural fields. Overall, countries such as Canada, Mexico and the USA reported higher concentrations of DDT, chlordane, $p, p^{\prime}$-DDE and toxaphene in air $[148,149]$. According to the spatial comparison data, in spring season, the concentration of organochlorine compounds is increased compared to other seasons [150].

In most of the studies conducted in South America, chlorpyrifos, endosulfan, and cypermethrin are frequently found pesticides in water bodies [151, 152]. Albuquerque et al. [153] reported the presence of 21 herbicides, 11 fungicides, 10 insecticides and 1 plant growth regulators in surface waters of Brazil. Azinophos-methyl and chlorpyrifos were most frequently detected pesticides in surface waters and soils of Neuquén River valley of Argentina [154]. De Gerónimo et al. [155] reported that atrazine, tebuconazole and diethyltoluamide were the most detected pesticides in surface water sub-basins of Argentina. Resgalla et al. [156] conducted study to evaluate the risk due to residues of herbicide quinclorac in irrigated water against zooplankton and phytoplankton. They reported that recommended application of concentration of quinclorac has short-term indirect effects on zooplankton, but it directly affects phytoplankton. 
The application of pesticides might harm the indigenous microorganisms of soil and affect the soil ecosystem, thus entering in food chain and affecting human health [157]. Pesticides interplay with soil microbes and their activities and thus change the biochemical and physiologic behavior of soil microbes [158]. Pesticides also have negative impact on soil microbial biomass and soil respiration [159]. It has been found that pesticides reduce natural symbiotic nitrogen fixation, leading to the decrease in crop yield. Pesticides like DDT, methyl parathion and pentachlorophenol interfere with signaling between leguminous plants and symbiotic soil bacteria. This results in enhanced dependence on synthetic nitrogen fertilizers along with reduced soil fertility and unsustainable crop yield [160, 161]. Daly et al. [162] reported the contamination of air and soil of Costa Rica and found that the concentration of DDT-related species was more as compared to other organochlorine pesticides used in the country. The distribution of pesticides in the soil of Canada was also determined by Daly et al. [162] by collecting soil from 22 sites. Endosulfan, dieldrin and $a$-hexachlorocyclohexane were the most prevalent OCPs in the soil of Canada [162]. The distribution of different pesticides in the soil mainly depends on the physical and chemical properties of soil. The amount of pesticides contamination in soils of southern Mexico was investigated by Wong et al. [102], and the results showed higher concentration of DDT in the range of $0.057-360 \mathrm{ng} / \mathrm{g}$. Luchini et al. [163] determined high concentrations of pesticides in soils which included trifluralin and endosulfan from cotton-cropped fields in Brazil. Nakagawa et al. [164] reported the presence of high atrazine percentage in the soils of São Paulo State of Brazil. Miglioranza et al. [165] concluded that pesticides in soil environment of Argentina are present in such a concentration, which may cause threat to various tropical levels.

Pesticide contamination in the ecosystems also badly impacts other organisms like bees and wild life. In the past one decade, there is an enhancement in illegal usage of pesticides [166]. This has led to misuse and abuse of the wildlife, for example drastic effect on most raptor species like Gypaestus barbatus (bearded vulture) [167] and Aquila adalberli (imperial eagle) [168]. Other important components of ecosystems which are negatively affected by pesticide overuse are biological pest control [169], soil fertility [170] and proper crop pollination [171]. In Peru, (the Punta San Juan Marine Protected Area), Adkesson et al. [172] studied the blood of endangered species, Humboldt penguins (Spheniscus humboldti), to find out the presence of organochlorine pesticides. They reported high concentration of DDT with maximum concentration of $10 \mathrm{ng} / \mathrm{g}$. The presence of these toxicants emphasize upon the need of temporal monitoring to protect this endangered species. In Uruguay, Pareja et al. [173] estimated the pesticide residues in 14,800 beehives and found high concentrations of coumaphos, endosulfan, ethion, chlorpyrifos and cypermethrin from active beehives. They reported that these pesticide residues cause bee disorientation and affect their global fitness which leads to weakness and productivity decrease.

The regular use of pesticides has also caused problems like human health issues and environmental problems [174]. It has been reported that for human health, food intake leads to higher toxicity exposure than by other means like drinking water and inhalation [175]. The pesticides mimic or antagonize natural hormones in human body. Long-term low-dose exposure affects human health with reducing immunity, disturbs hormonal balance, reduces intelligence and causes reproduction-related problems and cancer [176]. Farmers are generally at high risk of exposure to pesticides, herbicides, fertilizers and other chemicals. It has been found by Alavanja et al. [177] that use of chlorinated pesticides and methyl bromide is associated with prostate cancer risk in farmers. Similarly, Hoppin et al. [178] reported that pesticide exposure increases the chance of allergic and non-allergic asthma in farmers.

Kostik et al. [179] determined amount of pesticide residues in plant-based foods. Experimentation was carried out as per recommendation of European Food Authority (EFSA). In the period of 2012-2013, approximately 168 different samples of fresh vegetables like cherry, grapes, apple and manufactured jams and canned fruits had 33 different pesticides residues. The most predominant residues found were metalaxyl $(0.4-0.16 \mathrm{mg} / \mathrm{kg})$, methomyl $(0.015-0.21 \mathrm{mg} / \mathrm{kg})$ and imidacloprid $(0.017-0.036 \mathrm{mg} / \mathrm{kg})$. In another significant study conducted to estimate pesticide levels in sweet cherry in the farmland of West Mediterranean region of Turkey, it was observed that $53,349.5 \mathrm{~g} /$ ha of agricultural chemicals had an active constituents in the sweet cheery plants. The percentage of copper sulfate, pesticide and mineral oils is $79.82 \%, 19.11 \%$ and $1.07 \%$, respectively [180]. This pesticide contamination of fruits and vegetables is a serious issue for humans.

\section{Conclusion and future perspectives}

Synthetic pesticides are used to control the weeds and insect pests, affecting the agricultural systems. Water, soil and air serve as an important medium for transportation of pesticides from one site to another. Among different classes of pesticides, organochlorine pesticides are the most harmful one due to their slow rate of decomposition, greater stability and long half-life. These pesticides can migrate and get accumulated in the upper trophic levels of food chain. Pesticide contamination is a serious 
problem for each ecosystem and is harmful for all associated organisms. So, in order to control pesticide usage, new methodologies and techniques are needed in assessing the effect of widespread use of pesticides on ecosystem and efforts should be made to provide awareness among public to minimize the application of harmful pesticides. Use of biopesticides should be encouraged over chemical pesticides.

\section{Compliance with ethical standards}

Conflict of interest The authors declare that they have no conflict of interest.

\section{References}

1. Abhilash PC, Singh N (2009) Pesticide use and application: an Indian scenario. J Hazard Mater 165(1-3):1-12. https://doi. org/10.1016/j.jhazmat.2008.10.061

2. UNEP (2007) Stockholm Convention on Persistent Organic Pollutants (POPs). United Nations Environment Programme. doi:http://www.pops.int

3. Vos JG, Dybing E, Greim HA, Ladefoged O, Lambre C, Tarazona JV, Brandt I, Vethaak AD (2000) Health effects of endocrinedisrupting chemicals on wildlife, with special reference to the European situation. Crit Rev Toxicol 30(1):71-133. https://doi. org/10.1080/10408440091159176

4. UNEP (2001) Stockholm Convention on Persistent Organic Pollutants (POPs). United Nations Environment Programme. doi:http://www.pops.int/

5. De A, Bose R, Kumar A, Mozumdar S (eds) (2014) Worldwide pesticide use. In: Targeted delivery of pesticides using biodegradable polymeric nanoparticles. Springer, Berlin, pp 5-6

6. Worldatlas (2018) https://www.worldatlas.com/articles/toppesticide-consuming-countries-of-the-world.html

7. Zhang W (2018) Global pesticide use: profile, trend, cost/benefit and more. Proc Int Acad Ecol Environ Sci 8(1):1-27

8. Taylor MD, Klaine SJ, Carvalho FP, Barcelo D (2002) Pesticide residues in coastal tropical ecosystems: distribution, fate and effects. CRC Press, Boca Raton

9. Sharma A, Kumar V, Bhardwaj R, Thukral AK (2017) Seed presoaking with 24-epibrassinolide reduces the imidacloprid pesticide residues in green pods of Brassica juncea L. Toxicol Environ Chem 99(1):95-103

10. Daines RH (1952) 2, 4-D as an air pollutant and its effects on various species of plants. In: Air pollution, proceedings of the US technical conference on air pollution. McGraw-Hill Book Co, New York, pp 140-143

11. Donal PF, Gree RE, Heath MF (2001) Agricultural intensification and the collapse of Europe's farmland bird populations. Proc Biol Sci 268(1462):25-29. https://doi.org/10.1098/ rspb.2000.1325

12. Waite DT, Bailey P, Sproull JF, Quiring DV, Chau DF, Bailey J, Cessna AJ (2005) Atmospheric concentrations and dry and wet deposits of some herbicides currently used on the Canadian Prairies. Chemosphere 58(6):693-703. https://doi. org/10.1016/j.chemosphere.2004.09.105

13. Shen L, Wania F, Lei YD, Teixeira C, Muir DC, Bidleman TF (2005) Atmospheric distribution and long-range transport behavior of organochlorine pesticides in North America. Environ Sci Technol 39(2):409-420. https://doi.org/10.1021/ es049489c

14. Agnihotri NP, Gajbhiye VT, Kumar M, Mohapatra SP (1994) Organochlorine insecticide residues in Ganga river water near Farrukhabad, India. Environ Monit Assess 30(2):105-112. https ://doi.org/10.1007/bf00545617

15. Pereira JL, Antunes SC, Ferreira AC, Goncalves F, Pereira R (2010) Avoidance behavior of earthworms under exposure to pesticides: is it always chemosensorial? J Environ Sci Health $B$ 45(3):229-232. https://doi.org/10.1080/03601231003613625

16. Sharma BM, Bharat GK, Tayal S, Nizzetto L, Cupr P, Larssen T (2014) Environment and human exposure to persistent organic pollutants (POPs) in India: a systematic review of recent and historical data. Environ Int 66:48-64. https://doi.org/10.1016/j. envint.2014.01.022

17. Sharma A, Kumar V, Kumar R, Shahzad B, Thukral AK, Bhardwaj $R$ (2018) Brassinosteroid-mediated pesticide detoxification in plants: a mini-review. Cog Food Agric 4(1):1436212

18. Sharma A, Kumar V, Thukral A, Bhardwaj R (2019) Responses of Plants to Pesticide Toxicity: an Overview. Planta Daninha 37:e019184291

19. Sharma A, Kumar V, Handa N, Bali S, Kaur R, Khanna K, Thukral AK, Bhardwaj R (2018) Potential of endophytic bacteria in heavy metal and pesticide detoxification. In: Egamberdieva D, Ahmad P (eds) Plant microbiome: stress response. Springer, Berlin, pp 307-336

20. Abate T, van Huis A, Ampofo JK (2000) Pest management strategies in traditional agriculture: an African perspective. Annu Rev Entomol 45:631-659. https://doi.org/10.1146/annur ev.ento.45.1.631

21. Snyder J, Smart J, Goeb J, Tschirley D (2015) Pesticide use in Sub-Saharan Africa: estimates, projections, and implications in the context of food system transformation. IIAM Research Report No. 8E. https://doi.org/10.22004/ag.econ.230980

22. K. L, V.C. J, V R A Review of Pesticide use in EU and African Countries and Associated Polices. In: Proceedings of 120th The IIER international conference, Port Louis, Mauritius, 2017. pp 44-50

23. De Bon H, Huat J, Parrot L, Sinzogan A, Martin T, Malezieux E, Vayssieres J-F (2014) Pesticide risks from fruit and vegetable pest management by small farmers in sub-Saharan Africa. A review. Agron Sustain Dev 34(4):723-736

24. Jepson PC, Guzy M, Blaustein K, Sow M, Sarr M, Mineau P, Kegley $S$ (2014) Measuring pesticide ecological and health risks in West African agriculture to establish an enabling environment for sustainable intensification. Philos Trans R Soc Lond B Biol Sci 369(1639):20130491. https://doi.org/10.1098/rstb.2013.0491

25. van der Valk H (2003) Strategic program for pesticide management in the Sahel: a vision for 2003-2007. Sahelian pesticide committee (CSP)

26. PRRP (2012) Workshop on post registration and sustainability of pesticide management. APHRD of MoA and PRRP- Ethiopia, Hiruy Hall Addis Ababa

27. Obopile M, Munthali D, Matilo B (2008) Farmers' knowledge, perceptions and management of vegetable pests and diseases in Botswana. Crop Prot 27(8):1220-1224

28. Oluwole O, Cheke RA (2009) Health and environmental impacts of pesticide use practices: a case study of farmers in Ekiti State, Nigeria. Int J Agric Sustain 7(3):153-163

29. Nyirenda SP, Sileshi GW, Belmain SR, Kamanula JF, Mvumi BM, Sola P, Nyirenda GK, Stevenson PC (2011) Farmers' ethno-ecological knowledge of vegetable pests and pesticidal plant use in Malawi and Zambia. Af J Agric Res 6(6):1525-1537

30. Williamson S, Ball A, Pretty J (2008) Trends in pesticide use and drivers for safer pest management in four African countries. Crop Prot 27(10):1327-1334 
31. Martin T, Ochou GO, Hala-N'Klo F, Vassal JM, Vaissayre M (2000) Pyrethroid resistance in the cotton bollworm, Helicoverpa armigera (Hübner), West Africa. Pest Manag Sci 56(6):549-554

32. Carletto J, Martin T, Vanlerberghe-Masutti F, Brévault T (2010) Insecticide resistance traits differ among and within host races in Aphis gossypii. Pest Manag Sci 66(3):301-307

33. Houndete TA, Ketoh GK, Hema OS, Brevault T, Glitho IA, Martin $\mathrm{T}$ (2010) Insecticide resistance in field populations of Bemisia tabaci (Hemiptera: Aleyrodidae) in West Africa. Pest Manag Sci 66(11):1181-1185. https://doi.org/10.1002/ps.2008

34. Kunstadter P (2007) Pesticides in Southeast Asia: environmental, biomedical, and economic uses and effects. Silkworm Books, Ms Trasvin

35. Schreinemachers P, Tipraqsa P (2012) Agricultural pesticides and land use intensification in high, middle and low income countries. Food Policy 37(6):616-626

36. Schreinemachers P, Afari-Sefa V, Heng CH, Dung PTM, Praneetvatakul S, Srinivasan R (2015) Safe and sustainable crop protection in Southeast Asia: status, challenges and policy options. Environ Sci Policy 54:357-366

37. Gupta P (2004) Pesticide exposure-Indian scene. Toxicology 198(1-3):83-90

38. Khan MJ, Zia MS, Qasim M (2010) Use of pesticides and their role in environmental pollution. World Acad Sci Eng Technol 72:122-128

39. Pozo K, Harner T, Lee SC, Sinha RK, Sengupta B, Loewen M, Geethalakshmi V, Kannan K, Volpi V (2011) Assessing seasonal and spatial trends of persistent organic pollutants (POPs) in Indian agricultural regions using PUF disk passive air samplers. Environ Pollut (Barking, Essex: 1987) 159(2):646-653. https:// doi.org/10.1016/j.envpol.2010.09.025

40. Jabbar A, Mallick S (1994) Pesticides and environment situation in Pakistan. Sustainable Development Policy Institute Islamabad, Islamabad

41. Syed JH, Malik RN (2011) Occurrence and source identification of organochlorine pesticides in the surrounding surface soils of the Ittehad Chemical Industries Kalashah Kaku, Pakistan. Environ Earth Sci 62(6):1311-1321

42. Ahad K, Mohammad A, Khan H, Ahmad I, Hayat Y (2010) Monitoring results for organochlorine pesticides in soil and water from selected obsolete pesticide stores in Pakistan. Environ Monit Assess 166(1-4):191-199. https://doi.org/10.1007/s1066 1-009-0995-5

43. Rahman S (2005) Environmental impacts of technological change in Bangladesh agriculture: farmers' perceptions, determinants, and effects on resource allocation decisions. Agric Econ 33(1):107-116

44. SHELGA (2006) Nepal country situation report on persistent organic pollutants (POPs). Society for Human Rights, Environment. Law and Governance Activities, New Baneshwor

45. Lamers M, Schreinemachers P, Ingwersen J, Berger T, Sangchan W, Grovermann C (2013) Agricultural pesticide use in mountainous areas of Southeast Asia: towards reducing exposure and rationalizong use. In: Fr€ohlich HL, Schreinemachers $\mathrm{P}$, Stahr K, Clemens G (eds) Sustainable land use and rural development in southeast Asia: innovations and policies for mountainous areas. Springer, Berlin, pp 109-148

46. Zhang W, Jiang F, Ou J (2011) Global pesticide consumption and pollution: with China as a focus. Proc Int Acad Ecol Environ Sci 1(2):125

47. FAO (2017) Pesticide residues in food. Joint FAO/WHO Meeting on Pesticide Residues. Food and Agriculture Organization of the United Nations, WHO, Rome

48. Llewellyn R, Ronning D, Clarke M, Mayfield A, Walker S, Ouzman $\mathrm{J}$ (2016) Impact of weeds in Australian grain production. Grains Research and Development Corporation, Canberra
49. Radcliffe J (2002) Pesticide use in Australia. Australian Academy of Technological Sciences and Engineering, Melbourne

50. Walsh MJ, Powles SB (2007) Management strategies for herbicide-resistant weed populations in Australian dryland crop production systems. Weed Technol 21(2):332-338

51. Boutsalis P, Gill GS, Preston C (2012) Incidence of herbicide resistance in rigid ryegrass (Lolium rigidum) across southeastern Australia. Weed Technol 26(3):391-398

52. Bajwa AA, Walsh M, Chauhan BS (2017) Weed management using crop competition in Australia. Crop Prot 95:8-13

53. Owen MJ, Martinez NJ, Powles SB (2015) Multiple herbicideresistant wild radish (Raphanus raphanistrum) populations dominate Western Australian cropping fields. Crop Past Sci 66(10):1079-1085

54. Walsh MJ, Powles SB (2014) Management of herbicide resistance in wheat cropping systems: learning from the Australian experience. Pest Manag Sci 70(9):1324-1328. https://doi. org/10.1002/ps.3704

55. Heap I (2014) Global perspective of herbicide-resistant weeds. Pest Manag Sci 70(9):1306-1315

56. Broster J, Pratley J (2006) A decade of monitoring herbicide resistance in Lolium rigidum in Australia. Aus J Exp Agric 46(9):1151-1160

57. Owen MJ, Walsh MJ, Llewellyn RS, Powles SB (2007) Widespread occurrence of multiple herbicide resistance in Western Australian annual ryegrass (Lolium rigidum) populations. Aus J Agric Res 58(7):711-718

58. Owen MJ, Goggin DE, Powles SB (2012) Identification of resistance to either paraquat or ALS-inhibiting herbicides in two Western Australian Hordeum leporinum biotypes. Pest Manag Sci 68(5):757-763. https://doi.org/10.1002/ps.2323

59. Owen MJ, Martinez N, Powles SB (2014) Multiple herbicide-resistant Lolium rigidum (annual ryegrass) now dominates across the Western Australian grain belt. Weed Res 54(3):314-324

60. Broster J, Koetz E, Wu H (2011) Herbicide resistance in wild oats ('Avena'Spp.) in Southern New South Wales. Plant Protect Quart 26(3):106

61. Ahmad-Hamdani M, Owen MJ, Yu Q, Powles SB (2012) ACCaseinhibiting herbicide-resistant Avena spp. populations from the Western Australian grain belt. Weed Technol 26(1):130-136

62. Heap I (2009) The international survey of herbicide resistant weeds. http://www.weedscience.com. Accessed 26 June 2015

63. Owen MJ, Powles SB (2016) The frequency of herbicide-resistant wild oat (Avena spp.) populations remains stable in Western Australian cropping fields. Crop Past Sci 67(5):520-527

64. Peterson MA, Collavo A, Ovejero R, Shivrain V, Walsh MJ (2018) The challenge of herbicide resistance around the world: a current summary. Pest Manag Sci 74(10):2246-2259

65. Attwood S, Maron M, House A, Zammit C (2008) Do arthropod assemblages display globally consistent responses to intensified agricultural land use and management? Global Ecol Biogeo 17(5):585-599

66. Hendrickx F, Maelfait JP, Van Wingerden W, Schweiger O, Speelmans M, Aviron S, Augenstein I, Billeter R, Bailey D, Bukacek R (2007) How landscape structure, land-use intensity and habitat diversity affect components of total arthropod diversity in agricultural landscapes. J Appl Ecol 44(2):340-351

67. Kristoffersen P, Rask AM, Grundy A, Franzen I, Kempenaar C, Raisio J, Schroeder H, Spijker J, Verschwele A, Zarina L (2008) A review of pesticide policies and regulations for urban amenity areas in seven European countries. Weed Res 48(3):201-214

68. Savela M-L, Hynninen E-L (2004) Slower growth in pesticide sales. KEMIA KEMI 31(6):57-59

69. Karasali H, Hourdakis A, Anagnostopoulos H, Doulia D (2002) Pesticide residues in thermal mineral water in Greece. J 
Environ Sci Health B 37(5):465-474. https://doi.org/10.1081/ pfc-120014876

70. Kucher O (2007) Ukrainian agriculture and agri-environmental concern. Univ. für Bodenkultur, Department für Wirtschafts-und Sozialwiss., Inst. für

71. EEA (2003) Europe's environment: The third assessment. European Environment Agency, Environmental assessment report No 10:341

72. Moklyachuk L, Drebot O, Moklyachuk O, Moklyachuk T, Monarh V (2014) Ecological risks from contamination of Ukrainian soils by persistent organic pollutants. Environ Ecol Res 2(1):27-34

73. GIS (2003) Goričko informativna stran. Nas kmetje ogrožajo? Kdo nas pa prehranruje? http://www.goricko.net/artic le.php?story $=20031216145610619 \&$ mode $=$ print. Accessed 15 Jan 2004

74. Fava L, Orrù MA, Scardala S, Alonzo E, Fardella M, Strumia C, Martinelli A, Finocchiaro S, Previtera M, Franchi A (2010) Pesticides and their metabolites in selected Italian groundwater and surface water used for drinking. Annali dell'Istituto superiore di sanita 46:309-316

75. Ferencz L, Balog A (2010) A pesticide survey in soil, water and foodstuffs from central Romania. Carpath J Earth Environ Sci $5(1): 111-118$

76. Kristoffersen P, Rask AM (2007) Undersøgelse af pesticidforbruget på offentlige arealer i 2006

77. Hansen PK, Kristoffersen P, Kristensen K (2004) Strategies for non-chemical weed control on public paved areas in Denmark. Pest Manag Sci 60(6):600-604. https://doi.org/10.1002/ ps.853

78. Grundy A (2007) Weed occurrence on pavements in the UK: the results from a survey of Leamington Spa. Aspect Appl Biol 82:175

79. Gianessi L (2014) Importance of Pesticides for Growing Wheat in Sub-Saharan Africa. International Pesticide Benefits Case Study No. 104, August 2014

80. Jess S, Kildea S, Moody A, Rennick G, Murchie AK, Cooke LR (2014) European Union policy on pesticides: implications for agriculture in Ireland. Pest Manag Sci 70(11):1646-1654. https ://doi.org/10.1002/ps.3801

81. Lavery M, Withers J, Jess S, Matthews D, Patton A, Kelly T (2015) Northern Ireland Top Fruit Crops 2014. Pesticide usage survey report 241, Belfast, UK

82. Carvalho F, Fowler S, Villeneuve J, Horvat M (1997) Pesticide residues in the marine environment and analytical quality assurance of the results. In: Environmental behaviour of crop protection chemicals. In: Proceeding of an FAO-IAEA international symposium. International atomic energy agency, Vienna. pp 35-57

83. Ross G (2005) Risks and benefits of DDT. Lancet 366(9499):1771-1772

84. Pimentel D, Burgess M (2014) Environmental and economic costs of the application of pesticides primarily in the United States. In: Pimentel D, Peshin R (eds) Integrated pest management. Springer, Berlin, pp 47-71

85. Pimentel D, Greiner A (1997) Environmental and socio-economic costs of pesticide use. In: Pimentel D (ed) Techniques for reducing pesticide use: environmental and economic benefits. John, Chichester, pp 51-78

86. Atwood D, Paisley-Jones C (2017) Pesticides industry sales and usage: 2008-2012 Market Estimates. US Environmental Protection Agency, Washington, DC

87. Montana TUo (2016) Research reveals widespread herbicide use on North American wildlands. ScienceDaily. www.scien cedaily.com/releases/2016/06/160629135806.htm. Accessed 29 Jan 2018
88. Pimentel D (1997) Techniques for reducing pesticide use: economic and environmental benefits, vol 632.96. Wiley, New York, p 38

89. Pimentel D, Zepp A (1991) Environmental and economic effects of reducing pesticide use. Bioscience 41(6):402

90. Wagner V, Antunes PM, Irvine M, Nelson CR (2017) Herbicide usage for invasive non-native plant management in wildland areas of North America. J Appl Ecol 54(1):198-204

91. Benbrook CM (2016) Trends in glyphosate herbicide use in the United States and globally. Environ Sci Eur 28(1):3. https://doi. org/10.1186/s12302-016-0070-0

92. (AMR) AMR (2014) Global Herbicides Market -(Type, Mode of Action, Crop Type, Geography) Size, Industry Analysis, Trends, Opportunities, Growth and Forecast, 2013-2020. http://www. alliedmarketresearch.com/. Accessed 8 July 2018

93. Cessna AJ, Sheedy C, Farenhorst A, McQueen DAR (2010) Pesticides. In: Eilers W, MacKay R, Graham L, Lefebvre A (eds) Environmental Sustainability of Canadian agriculture: agrienvironmental indicator report series - report \#3. Agriculture and Agri-Food Canada Ottawa, Ontario, pp 101-107

94. Canada CPlo (2000) Survey of sales of pest control products for the year ending December 31, 1998. Etobicoke, Canada

95. Gagnon G, Lecavalier C, François S, Lawrence J, Tait M, Wang J (2014) Human activity and the environment. Statistics Canada - Catalogue no. 16-201-X. https://www150.statcan.gc.ca/n1/ en/pub/16-201-x/16-201-x2014000-eng.pdf?st=KbAG16uz. Accessed 1 May 2019

96. Wilson J (2008) Agricultural pesticide use trends in Manitoba and 2, 4-D fate in soil. University of Manitoba

97. Verrin SM, Begg S, Ross P (2004) Pesticide use in British Columbia and the Yukon: an assessment of types, applications and risks to aquatic biota. Can Tech Rep Fish Aquat Sci 2517:225

98. Raimondo S, Mineau P, Barron MG (2007) Estimation of chemical toxicity to wildlife species using interspecies correlation models. Environ Sci Technol 41(16):5888-5894. https://doi. org/10.1021/es070359o

99. FAOSTAT F (2017) Pesticides Use. Food and Agriculture Organization of the United Nations. http://www.fao.org/faostat/ en/\#data/RP. Accessed 9 Dec 2017

100. Market MA (2017) Mexico Agrochemicals Market-by type and application-Industry shares, forecasts and trends (2017-2022). https://www.mordorintelligence.com/industry-reports/mexic o-agrochemicals-market. Accessed 8 July 2018

101. Li YF, Macdonald RW (2005) Sources and pathways of selected organochlorine pesticides to the Arctic and the effect of pathway divergence on $\mathrm{HCH}$ trends in biota: a review. Sci Total Environ 342(1-3):87-106. https://doi.org/10.1016/j.scito tenv.2004.12.027

102. Wong F, Alegria HA, Jantunen LM, Bidleman TF, SalvadorFigueroa M, Gold-Bouchot G, Ceja-Moreno V, Waliszewski SM, Infanzon R (2008) Organochlorine pesticides in soils and air of southern Mexico: chemical profiles and potential for soil emissions. Atmos Environ 42(33):7737-7745

103. NACEC (2003) DDT no longer used in North America; Fact Sheet DDT 04-2003. North American Commission for Environmental Cooperation, Sound Management of Chemicals, Montreal

104. Piña CM, Forcada SA (2004) Effects of an environmental tax on pesticides in Mexico. Indust Environ 27(2):33-36

105. Carvalho FP (2017) Pesticides, environment, and food safety. Food Energy Sec 6(2):48-60

106. Geografia IBd (2006) Censo agropecuário 2006: resultados preliminares. IBGE, Rio de Janeiro

107. ANDV (2009) Tecnologia em primeiro lugar. Associação Nacional de Defesa Vegetal, São Paulo

108. SINDAG (2012) Vendas de agrotóxicos por estados brasileiros. Sindicato Nacional da Indústria de Produtos para 
Defesa Agrícola.:http://www.sindag.com.br/EST9798990 0.zip. Accessed 8 July 2018

109. Soares WL, de Souza Porto MF (2009) Estimating the social cost of pesticide use: an assessment from acute poisoning in Brazil. Ecol Econom 68(10):2721-2728

110. CASAFE (2013) Mercado Argentino 2013 de Productos Fitosanitarios. Camara de Sanidad Agropecuaria y Fertilizantes. http://www.casafe.org. Accessed 23 Dec 2017

111. PwC (2014) Agronegocios en Argentina. Año 2014 https ://www.pwc.com.ar/es/agribusiness/publicaciones/asset s/agribusiness-en-argentina-booklet-2014-ultimo.pdf. Accessed 13 Jan 2017

112. Cárdenas O, Silva E, Ortiz JE (2010) Uso de plaguicidas inhibidores de acetilcolinesterasa en once entidades territoriales de salud en Colombia, 2002-2005. Biomédica 30(1):95-106

113. Abong'o D, Wandiga S, Jumba I, Madadi V, Kylin H (2014) Impacts of pesticides on human health and environment in the River Nyando catchment, Kenya. Int J Hum Arts Med Sci 2(3): $1-14$

114. van der Werf HM (1996) Assessing the impact of pesticides on the environment. Agric Ecosyst Environ 60(2-3):81-96

115. Ahouangninou $C$, Martin T, Edorh $P$, Bio-Bangana $S$, Samuel O, St-Laurent L, Dion S, Fayomi B (2012) Characterization of health and environmental risks of pesticide use in marketgardening in the rural city of Tori-Bossito in Benin, West Africa. J Environ Protect 3(3):241-248

116. LVEMP/MoALDM (1999) Environmental, Technical SocioEconomic, Gender and Socio-Cultural issues in catchment conservation: Main Findings and Conclusions. Lake Victoria Environmental Management Project/Ministry of Agriculture, Livestock Development and Marketing, Nairobi, Kenya

117. Rasmussen JJ, Wiberg-Larsen P, Baattrup-Pedersen A, Cedergreen N, McKnight US, Kreuger J, Jacobsen D, Kristensen EA, Friberg N (2015) The legacy of pesticide pollution: an overlooked factor in current risk assessments of freshwater systems. Water Res 84:25-32

118. Sankararamakrishnan N, Kumar Sharma A, Sanghi R (2005) Organochlorine and organophosphorous pesticide residues in ground water and surface waters of Kanpur, Uttar Pradesh, India. Environ Int 31(1):113-120. https://doi.org/10.1016/j. envint.2004.08.001

119. Davies P, Cook L, Barton J (1994) Triazine herbicide contamination of Tasmanian streams: sources, concentrations and effects on biota. Mar Freshwater Res 45(2):209-226

120. Brodie J, De'Ath G, Devlin M, Furnas M, Wright M (2007) Spatial and temporal patterns of near-surface chlorophyll $a$ in the Great Barrier Reef lagoon. Marine Freshwater Res 58(4):342-353

121. Brodie J, Kroon F, Schaffelke B, Wolanski E, Lewis S, Devlin M, Bohnet I, Bainbridge Z, Waterhouse J, Davis A (2012) Terrestrial pollutant runoff to the Great Barrier Reef: an update of issues, priorities and management responses. Marine Pollut Bull 65(4-9):81-100

122. DeVantier L, De'Ath G, Turak E, Done T, Fabricius K (2006) Species richness and community structure of reef-building corals on the nearshore Great Barrier Reef. Coral Reefs 25(3):329-340

123. Fabricius K, De'ath G, McCook L, Turak E, Williams DM (2005) Changes in algal, coral and fish assemblages along water quality gradients on the inshore Great Barrier Reef. Marine Pollut Bull 51(1-4):384-398

124. Cantin NE, Negri AP, Willis BL (2007) Photoinhibition from chronic herbicide exposure reduces reproductive output of reef-building corals. Marine Ecol Prog Ser 344:81-93

125. Haynes D, Ralph P, Prange J, Dennison B (2000) The impact of the herbicide diuron on photosynthesis in three species of tropical seagrass. Marine Pollut Bull 41(7-12):288-293
126. Jones RJ, Muller J, Haynes D, Schreiber U (2003) Effects of herbicides diuron and atrazine on corals of the Great Barrier Reef, Australia. Marine Ecol Prog Ser 251:153-167

127. Magnusson M, Heimann K, Quayle P, Negri AP (2010) Additive toxicity of herbicide mixtures and comparative sensitivity of tropical benthic microalgae. Marine Pollut Bull 60(11):1978-1987

128. Kroon FJ, Kuhnert PM, Henderson BL, Wilkinson SN, KinseyHenderson A, Abbott B, Brodie JE, Turner RD (2012) River loads of suspended solids, nitrogen, phosphorus and herbicides delivered to the Great Barrier Reef lagoon. Marine Pollut Bull 65(4-9):167-181

129. Waterhouse J, Brodie J, Lewis S, Mitchell A (2012) Quantifying the sources of pollutants in the Great Barrier Reef catchments and the relative risk to reef ecosystems. Marine Pollut Bull 65(4-9):394-406

130. Davis AM, Lewis SE, Bainbridge ZT, Glendenning L, Turner RD, Brodie JE (2012) Dynamics of herbicide transport and partitioning under event flow conditions in the lower Burdekin region, Australia. Marine Pollut Bull 65(4-9):182-193

131. Davis A, Lewis S, Bainbridge Z, Brodie J, Shannon E (2008) Pesticide residues in waterways of the lower Burdekin region: challenges in ecotoxicological interpretation of monitoring data. Austr J Ecotoxicol 14(2/3):89

132. Stork PR, Bennett FR, Bell MJ (2008) The environmental fate of diuron under a conventional production regime in a sugarcane farm during the plant cane phase. Pest Manag Sci 64(9):954-963. https://doi.org/10.1002/ps.1593

133. Müller JF, Duquesne $S, N g$ J, Shaw GR, Krrishnamohan K, Manonmanii K, Hodge M, Eaglesham GK (2000) Pesticides in sediments from Queensland irrigation channels and drains. Marine Pollut Bull 41(7-12):294-301

134. Haynes D, Müller J, Carter S (2000) Pesticide and herbicide residues in sediments and seagrasses from the Great Barrier Reef World Heritage Area and Queensland coast. Marine Pollut Bull 41(7-12):279-287

135. Duke NC, Bell AM, Pederson DK, Roelfsema CM, Nash SB (2005) Herbicides implicated as the cause of severe mangrove dieback in the Mackay region, NE Australia: consequences for marine plant habitats of the GBR World Heritage Area. Marine Pollut Bull 51(1-4):308-324

136. Allinson $M$, Zhang $P$, Bui $A$, Myers JH, Pettigrove $V$, Rose $G$, Salzman SA, Walters R, Allinson G (2017) Herbicides and trace metals in urban waters in Melbourne, Australia (2011-12): concentrations and potential impact. Environ Sci Pollut Res Int 24(8):7274-7284. https://doi.org/10.1007/s1135 6-017-8395-9

137. Allinson G, Zhang P, Bui A, Allinson M, Rose G, Marshall S, Pettigrove V (2015) Pesticide and trace metal occurrence and aquatic benchmark exceedances in surface waters and sediments of urban wetlands and retention ponds in Melbourne, Australia. Environ Sci Pollut Res Int 22(13):10214-10226. https://doi.org/10.1007/s11356-015-4206-3

138. Shunthirasingham $C$, Gawor A, Hung $H$, Brice KA, Su K, Alexandrou N, Dryfhout-Clark H, Backus S, Sverko E, Shin C, Park R, Noronha R (2016) Atmospheric concentrations and loadings of organochlorine pesticides and polychlorinated biphenyls in the Canadian Great Lakes Basin (GLB): spatial and temporal analysis (1992-2012). Environ Pollut (Barking, Essex: 1987) 217:124-133. https://doi.org/10.1016/j.envpo I.2016.01.039

139. Reilly TJ, Smalling KL, Orlando JL, Kuivila KM (2012) Occurrence of boscalid and other selected fungicides in surface water and groundwater in three targeted use areas in the United States. Chemosphere 89(3):228-234. https://doi.org/10.1016/j.chemo sphere.2012.04.023 
140. Bidleman TF, Jantunen $L$, Harner T, Wiberg $K$, Wideman J, Brice K, Su K, Falconer R, Aigner E, Leone A (1998) Chiral pesticides as tracers of air-surface exchange. Environ Pollut 102(1):43-49

141. Karr J (2000) River conservation in the United States and Canada. In: Boon PJ, Davies BR, Petts GE (eds) Global perspectives on river conservation: science, policy, and practice. Wiley, Chichester, pp 3-39

142. Howe CM, Berrill M, Pauli BD, Helbing CC, Werry K, Veldhoen N (2004) Toxicity of glyphosate-based pesticides to four North American frog species. Environ Toxicol Chem 23(8):1928-1938

143. Solomon KR, Giesy JP, LaPoint TW, Giddings JM, Richards RP (2013) Ecological risk assessment of atrazine in North American surface waters. Environ Toxicol Chem 32(1):10-11

144. Murray DL (1994) Cultivating crisis: the human cost of pesticides in Latin America. University of Texas Press, Austin

145. Rainwater TR, Wu TH, Finger AG, Canas JE, Yu L, Reynolds KD, Coimbatore G, Barr B, Platt SG, Cobb GP, Anderson TA, McMurry ST (2007) Metals and organochlorine pesticides in caudal scutes of crocodiles from Belize and Costa Rica. Sci Total Environ 373(1):146-156. https://doi.org/10.1016/j.scito tenv.2006.11.010

146. Grieco JP, Achee NL, Andre RG, Roberts DR (2000) A comparison study of house entering and exiting behavior of Anopheles vestitipennis (Diptera: Culicidae) using experimental huts sprayed with DDT or deltamethrin in the southern district of Toledo, Belize, CA. J Vector Ecol 25(1):62-73

147. Carvalho FP, Villeneuve JP, Cattini C, Rendon J, Mota de Oliveira $J$ (2009) Pesticide and PCB residues in the aquatic ecosystems of Laguna de Terminos, a protected area of the coast of Campeche, Mexico. Chemosphere 74(7):988-995. https://doi. org/10.1016/j.chemosphere.2008.09.092

148. Hoh E, Hites RA (2004) Sources of toxaphene and other organochlorine pesticides in North America as determined by air measurements and potential source contribution function analyses. Environ Sci Technol 38(15):4187-4194. https://doi. org/10.1021/es0499290

149. Bailey R, Barrie L, Halsall CJ, Fellin P, Muir D (2000) Atmospheric organochlorine pesticides in the western Canadian Arctic: evidence of transpacific transport. J Geophy Res Atmos 105(D9):11805-11811

150. Hung $H$, Blanchard $P$, Halsall $C J$, Bidleman TF, Stern GA, Fellin P, Muir DC, Barrie LA, Jantunen LM, Helm PA, Ma J, Konoplev A (2005) Temporal and spatial variabilities of atmospheric polychlorinated biphenyls (PCBs), organochlorine (OC) pesticides and polycyclic aromatic hydrocarbons (PAHs) in the Canadian Arctic: results from a decade of monitoring. Sci Total Environ 342(1-3):119-144. https://doi.org/10.1016/j.scito tenv.2004.12.058

151. Hunt L, Bonetto C, Resh VH, Buss DF, Fanelli S, Marrochi N, Lydy MJ (2016) Insecticide concentrations in stream sediments of soy production regions of South America. Sci Total Environ 547:114-124. https://doi.org/10.1016/j.scitotenv.2015.12.140

152. Jergentz $S$, Mugni $H$, Bonetto $C$, Schulz R (2005) Assessment of insecticide contamination in runoff and stream water of small agricultural streams in the main soybean area of Argentina. Chemosphere 61(6):817-826. https://doi.org/10.1016/j.chemo sphere.2005.04.036

153. Albuquerque A, Ribeiro J, Kummrow F, Nogueira A, Montagner C, Umbuzeiro G (2016) Pesticides in Brazilian freshwaters: a critical review. Environ Sci: Processes Impacts 18(7):779-787

154. Loewy RM, Monza LB, Kirs VE, Savini MC (2011) Pesticide distribution in an agricultural environment in Argentina. J Environ Sci Health B 46(8):662-670. https://doi.org/10.1080/03601 234.2012.592051

155. De Geronimo E, Aparicio VC, Barbaro S, Portocarrero R, Jaime S, Costa JL (2014) Presence of pesticides in surface water from four sub-basins in Argentina. Chemosphere 107:423431. https://doi.org/10.1016/j.chemosphere.2014.01.039

156. Resgalla C, Noldin JA, Tamanaha MS, Deschamps FC, Eberhardt D, Rörig L (2007) Risk analysis of herbicide quinclorac residues in irrigated rice areas, Santa Catarina, Brazil. Ecotoxicology 16(8):565-571

157. Hussain S, Siddique T, Saleem M, Arshad M, Khalid A (2009) Impact of pesticides on soil microbial diversity, enzymes, and biochemical reactions. Adv Agron 102:159-200

158. Singh BK, Walker A (2006) Microbial degradation of organophosphorus compounds. FEMS Microbiol Rev 30(3):428-471

159. Zhou Y, Liu W, Ye H (2006) Effects of pesticides metolachlor and S-metolachlor on soil microorganisms in aquisols. II. Soil respiration. J Appl Ecol 17(7):1305-1309

160. Fox JE, Gulledge J, Engelhaupt E, Burow ME, McLachlan JA (2007) Pesticides reduce symbiotic efficiency of nitrogenfixing rhizobia and host plants. Proc Natl Acad Sci USA 104(24):10282-10287. https://doi.org/10.1073/pnas.06117 10104

161. Potera C (2007) Agriculture: pesticides disrupt nitrogen fixation. Environ Health Perspect 115(12):A579. https://doi. org/10.1289/ehp.115-a579a

162. Daly GL, Lei YD, Teixeira C, Muir DC, Castillo LE, Jantunen LM, Wania $F$ (2007) Organochlorine pesticides in the soils and atmosphere of Costa Rica. Environ Sci Technol 41(4):11241130. https://doi.org/10.1021/es062349d

163. Luchini LC, Peres TB, de Andrea MM (2000) Monitoring of pesticide residues in a cotton crop soil. J Environ Sci Health B 35(1):51-59. https://doi.org/10.1080/03601230009373253

164. Nakagawa L, Luchini L, Musumeci M, Matallo M (1996) Behavior of atrazine in soils of tropical zone: degradation, mobility and uptake of atrazine residues from soils in a crop rotation system (maize/beans). J Environ Sci Health B 31(2):203-224

165. Miglioranza KS, Aizpun de Moreno JE, Moreno VJ (2003) Dynamics of organochlorine pesticides in soils from a southeastern region of Argentina. Environ Toxicol Chem 22(4):712-717

166. Hernandez M, Margalida A (2008) Pesticide abuse in Europe: effects on the Cinereous vulture (Aegypius monachus) population in Spain. Ecotoxicology 17(4):264-272. https://doi. org/10.1007/s10646-008-0193-1

167. Margalida A, Heredia R, Razin M, Hernández M (2008) Sources of variation in mortality of the Bearded Vulture Gypaetus barbatus in Europe. Bird Conserv Int 18(1):1-10

168. González LM, Margalida A, Manosa S, Sánchez R, Oria J, Molina $\mathrm{Jl}$, Caldera J, Aranda A, Prada L (2007) Causes and spatio-temporal variations of non-natural mortality in the vulnerable Spanish imperial eagle Aquila adalberti during a recovery period. Oryx 41(4):495-502

169. Tscharntke T, Klein AM, Kruess A, Steffan-Dewenter I, Thies $C$ (2005) Landscape perspectives on agricultural intensification and biodiversity-ecosystem service management. Ecol Lett 8(8):857-874

170. Brussaard $L$ (1997) Biodiversity and ecosystem functioning in soil. Ambio 26:563-570

171. Biesmeijer JC, Roberts SP, Reemer M, Ohlemuller R, Edwards $M$, Peeters T, Schaffers AP, Potts SG, Kleukers R, Thomas CD, Settele $J$, Kunin WE (2006) Parallel declines in pollinators and insectpollinated plants in Britain and the Netherlands. Science (New York, NY) 313(5785):351-354. https://doi.org/10.1126/scien ce. 1127863

172. Adkesson MJ, Levengood JM, Scott JW, Schaeffer DJ, Langan JN Cardenas-Alayza S, de la Puente S, Majluf P, Yi S (2018) Assessment of Polychlorinated Biphenyls, Organochlorine Pesticides, and Polybrominated Diphenyl Ethers in the Blood of Humboldt Penguins (Spheniscus Humboldti) from the Punta San Juan 
Marine Protected Area, Peru. J Wildl Dis 54(2):304-314. https ://doi.org/10.7589/2016-12-270

173. Pareja L, Colazzo M, Perez-Parada A, Niell S, Carrasco-Letelier L, Besil N, Cesio MV, Heinzen H (2011) Detection of pesticides in active and depopulated beehives in Uruguay. Int J Environ Res Public Health 8(10):3844-3858. https://doi.org/10.3390/ijerp h8103844

174. Geiger F, Bengtsson J, Berendse F, Weisser WW, Emmerson $M$, Morales MB, Ceryngier P, Liira J, Tscharntke T, Winqvist C (2010) Persistent negative effects of pesticides on biodiversity and biological control potential on European farmland. Basic Appl Ecol 11(2):97-105

175. Margni M, Rossier D, Crettaz P, Jolliet O (2002) Life cycle impact assessment of pesticides on human health and ecosystems. Agric Ecosyst Environ 93(1-3):379-392

176. Yadav IC, Devi NL, Syed JH, Cheng Z, Li J, Zhang G, Jones KC (2015) Current status of persistent organic pesticides residues in air, water, and soil, and their possible effect on neighboring countries: a comprehensive review of India. Sci Total Environ 511:123-137. https://doi.org/10.1016/j.scitotenv.2014.12.041

177. Alavanja MC, Samanic C, Dosemeci M, Lubin J, Tarone R, Lynch CF, Knott C, Thomas K, Hoppin JA, Barker J (2003) Use of agricultural pesticides and prostate cancer risk in the agricultural health study cohort. Am J Epidemiol 157(9):800-814

178. Hoppin JA, Umbach DM, London SJ, Henneberger PK, Kullman GJ, Coble J, Alavanja MC, Beane Freeman LE, Sandler DP (2009) Pesticide use and adult-onset asthma among male farmers in the agricultural health study. Eur Respir J 34(6):1296-1303. https://doi.org/10.1183/09031936.00005509

179. Kostik V, Angelovska B, Kiroska-Petreska E, Bauer B (2014) Determination of pesticide residues in plant-based foods from the Republic of Macedonia. J Food Nutr Sci 2(4):124-129

180. Yilmaz H (2015) Farm level analysis of pesticide use in sweet cherry (Prunus avium L.) growing in West Mediterranean region of Turkey. Acta Scient Polon Hortor Cult 14(3):115-129

Publisher's Note Springer Nature remains neutral with regard to jurisdictional claims in published maps and institutional affiliations. 